\title{
TANGGUNG GUGAT PELAKU USAHA PERIKLANAN DITINJAU DARI PERLINDUNGAN KONSUMEN
}

\author{
Oleh \\ Ari Purwadi ${ }^{\star}$
}

\section{ABSTRAK}

Sengketa konsumen yang timbul dari pengelabuhan konsumen melalui iklan membebankan tanggung gugat periklanan kepada pelaku usaha periklanan, sedangkan tanggung gugat baru ditujukan kepada pelaku usaha pengiklan kalau konsumen dirugikan setelah mengkonsumsi produk itu. Ini merupakan konsekuensi dari prinsip professional liability. Konstruksi yuridis "tanggung gugat renteng" bisa digunakan apabila dapat dibuktikan kerugian konsumen akibat kesalahan pelaku usaha pengiklan maupun pelaku usaha periklanan. Tanggung gugat pelaku usaha periklanan dapat beralih kepada pelaku usaha pengiklan dengan menggunakan prinsip beban pembuktian terbalik.

Kata kunci : Tanggung gugat, pelaku usaha pengiklan, pelaku usaha periklanan, professional liability, tanggung gugat renteng.

\section{A. PENDAHULUAN}

Keberadaan usaha)

bagi

produsen merupakan suatu hal yang mutlak

sifatnya. Tanpa kehadiran konsumen, maka

produsen tidak mempunyai arti, mau

dikemanakan produknya, atau

mendapatkan keuntungan dari mana.

Sebaliknya keberadaan produsen (pelaku konsumen, karena konsumen membutuhkan sesuatu yang dihasilkan atau dipasarkan oleh produsen (pelaku usaha). Oleh karena itu dalam konteks hukum sebenarnya antara konsumen dan produsen (pelaku usaha) mempunyai hubungan timbal balik. Kewajiban produsen (pelaku

- Dosen Fakultas Hukum dan Magister Ilmu Hukum PPS Universitas Wijaya Kusuma Surabaya. 
usaha) merupakan hak konsumen, dan hak produsen (pelaku usaha) merupakan kewajiban konsumen secara wajar, seharusnya kedua belah pihak berada pada posisi atau kedudukan yang seimbang dalam arti saling menguntungkan dan tidak saling merugikan.

Secara formal dalam hukum positif telah diatur hak dan kewajiban masingmasing pihak baik konsumen maupun produsen (pelaku usaha) di dalam UndangUndang Perlindungan Konsumen (UndangUndang Nomor 8 Tahun 1999). Kehadiran Undang-Undang Perlindungan Konsumen dengan mengatur hak dan kewajiban masing-masing pihak bukanlah sesuatu yang akan merugikan produsen (pelaku usaha) melainkan justru dapat menimbulkan semangat untuk melakukan persaingan usaha yang sehat.

Di dalam dunia usaha, persaingan ini tidak dapat dihindarkan, karena hakekat praktek usaha (bisnis) itu adalah "bersaing". Persaingan antara pelaku usaha terjadi karena produk salah satu pelaku usaha akan bertemu dengan produk pélaku usaha yang lain di pasar. Persaingan usaha ini bisa dalam bentuk harga maupun non- harga. Persaingan melalui harga dilakukan dengan upaya untuk meningkatkan efisiensi agar biaya produksi dapat ditekan serendah mungkin, sehingga harga dapat bersaing di pasar. Persaingan non-harga dapat dilakukan diantaranya melalui iklan.

Dalam alam yang diwarnai dengan persaingan usaha sering konsumen cenderung berada dipihak yang dirugikan. Derasnya promosi dari iklan tanpa dilandasi tanggung jawab akan menjerumuskan pembeli (konsumen) pada barang yang kurang sesuai harapan. Disisi lain, agaknya snobisme, dan kerakusan untuk memiliki sesuatu produk yang berasal dari diri konsumen telah dimanfaatkan pelaku usaha untuk menutupi kekurangan produk dengan kemasan yang apik dan menarik. Bagi pelaku usaha, peranan pemasaran sangat besar dalam meningkatkan penjualan produk. Dewasa ini, pelaku usaha dituntut untuk memproduksi produk yang lebih kompetitif dan lebih bersifat kreatif dalam meningkatkan penjualan produknya. Dalam menjual produk yang kompetitif di pasaran, maka peran periklanan semakin besar dan berarti dalam memasarkan produk. Produk 
yang dihasilkan oleh perusahaan (pelaku usaha) periklanan, berupa iklan diharapkan mampu memberikan kepuasan bagi pengusaha pengiklan (produsen, distributor, supplier, retailer), sekaligus juga bagi para konsumen produk yang diiklankan.

Iklan sebagai sarana yang penting bagi produsen (pelaku usaha) untuk menarik minat konsumen menggunakan produk yang ditawarkan. Suatu produk dapat dipahami oleh konsumen melalui informasi produk yang diberikan oleh produsen. Informasi produk ini biasanya dilakukan dengan iklan. Iklan yang dibuat tentunya dituntut agar selalu mengatakan hal yang benar kepada konsumen. Kebutuhan pokok konsumen adalah mendapatkan informasi yang benar (jujur) dan bertanggung jawab sebelum konsumen mengambil keputusan untuk membeli, atau menunda atau bahkan tidak melakukan transaksi sama sekali. Kebenaran informasi produk akan menentukan pilihan konsumen yang benar terhadap produk yang ditawarkan.

Bagaimana kalau terjadi iklan yang menarik konsumen agar membeli produk dengan memberikan kesan dan pesan yang berlebihan tanpa memperhatikan nilai kejujuran dan kebenaran. Iklan yang tidak benar (tidak jujur) dan menyesatkan ini dapat dikategorikan sebagai perbuatan penipuan, yang pada akhirnya dapat menimbulkan kerugian bagi konsumen. Fenomena yang terjadi, materi iklan hanyalah merupakan informasi "mendorong" untuk membeli dan bukan memberikan informasi alasan secara sosialekonomi mengapa konsumen harus membeli produk tertentu. Bahkan timbul kesan", iklan adalah alat "membujuk" konsumen agar tertarik pada produk yang ditawarkan.

Iklan yang tidak benar (tidak jujur) dan menyesatkan tentu tidak dapat dipertanggungjawabkan. Dengan demikian, berdasarkan aspek hukum perdata tentu konsumen mempunyai hak untuk menuntut ganti rugi. Persoalannya sekarang adalah siapakah yang harus bertanggung-gugat, mengingat pihak-pihak yang terlibat adalah pelaku usaha (produsen/ pengusaha pengiklan) dan pelaku usaha periklanan, yang meliputi pihak media iklan dan pihak biro iklan. 


\section{B. PERMASALAHAN}

Oleh karena itu, tulisan ini mencoba mengetengahkan permasalahan : siapakah yang bertanggung gugat apabila terjadi iklan yang tidak benar (tidak jujur) dan menyesatkan ini merugikan konsumen, dan bagaimanakah kemungkinan dilakukan tanggung gugat (liability) secara tanggung renteng.

\section{PEMBAHASAN}

\section{a. Tanggung Gugat Dalam Kerangka}

\section{Perlindungan Konsumen}

Berbicara pertanggungjawaban dalam sengketa konsumen ${ }^{1}$ eliputi aspek hukum perdata, aspek hukum pidana, dan aspek hukum administrasi. ${ }^{2}$ ada dasarnya

1 Yang dimaksud dengan sengketa konsumen adalah sengketa yang terjadi antara pelaku usaha dan konsumen.

Undang-Undang Nomor 8 Tahun 1999 Tentang Perlindungan Konsumen telah memperkenalkan lembaga, yang dinamakan Badan Penyelesaian Sengketa Konsumen adalah badan yang bertugas menangani dan menyelesaikan sengketa antara pelaku usaha dan konsumen. (pasal 1 angka 11)

2 Aspek pertanggungjawaban tersebut diatur dalam Undang-Undang Nomor 8 Tahun 1999 Tentang Perlindungan Konsumen.

Aspek hukum perdata menimbulkan tanggunggugat (liability) berupa gugatan ganti kerugian (pasal 19) .Aspek hukum pidana menimbulkan pertanggungjawaban pidana (criminal responsibility) berupa tuntutan pidana (pasal 61) Aspek hukum administrasi menimbulkan penjatuhan sanksi administratif (pasal 60). transaksi konsumen ${ }^{3}$ itu dilaksanakan dengan memenuhi hak dan kewajiban masing-masing pihak. Manakala terjadi pelanggaran hak, maka menimbulkan tuntutan hak, yang apabila dilakukan proses litigasi menimbulkan sengketa konsumen.

Pertanggungjawaban perdata lazimnya disebut dengan tanggung gugat (liability). Secara sederhana Roscoe Pound mengartikan liability sebagai suatu situasi dimana seseorang boleh meminta sesuatu berdasarkan hukum, dan pihak yang lain secara hukum tunduk pada permintaan itu.

4 Selanjutnya Roscoe Pound menyatakan "thus the basis of liability has become two fold. It rests on the one hand upon duty to repair injury. It rests on the other hand upon duty to carry out formal undertaking. ${ }^{5}$

Dengan demikian, liability ini menimbulkan suatu kewajiban untuk

3 Yang dimaksud dengan "transaksi konsumen" adalah proses terjadinya peralihan pemilikan atau peningkatan barang atau jasa dari penyedia barang atau penyelenggara jasa kepada konsumen.

${ }^{4}$ Roscoe Pound, An Introduction To The Philosophy of Law, The Colonial Press Inc, Clinton, Massachussets, 1975, h. 74

$$
{ }^{5} \text { Ibid. , h. } 76
$$


membayar ganti rugi baik untuk memulihkan keadaan karena adanya kerusakan maupun untuk melaksanakan kewajiban berdasarkan janji secara formal. Senada dengan itu, Kitab Undang-Undang Hukum Perdata Indonesia (untuk selanjutnya ditulis BW) mengenal 2 bentuk dasar hukum untuk melaksanakan gugatan, yaitu berdasarkan wanprestasi (ingkar janji) dan perbuatan melanggar hukum (onrechtmatigedaad).

Pelanggaran kewajiban yang terletak dalam suatu perikatan berarti wanprestasi. Sedangkan pelanggaran yang tidak berakar dalam suatu perikatan menimbulkan perbuatan melanggar hukum. ${ }^{6}$

\section{Materi liability (tanggung gugat)} dalam kerangka perlindungan konsumen dapat digambarkan sebagai berikut :

1. Dalam hal terdapat hubungan perjanjian antara pelaku usaha (barang atau jasa) dan konsumen, maka tanggung gugat pelaku usaha didasarkan pada tanggung gugat kontraktual (contractual liability).

${ }^{6}$ J. H. Nieuwenhuis, Pokok-Pokok Hukum Perikatan, Terjemahan Djasadin Saragih, tanpa penerbit, Surabaya, 1985, h. 116
Tanggung gugat kontraktual yaitu tanggungjawab perdata atas dasar perjanjian (kontrak) dari pelaku usaha (barang atau jasa) atas kerugian yang dialami konsumen mengkonsumsi barang yang dihasilkan pelaku usaha atau memanfaatkan jasa yang diberikan pelaku usaha;

2. Dalam hal tidak terdapat hubungan perjanjian (tidak ada kontrak) antara pelaku usaha (produsen barang) dengan konsumen, maka tanggung jawab perdata pelaku usaha didasarkan pada tanggung gugat produk (product liability).

Tanggung gugat produk yaitu tanggung jawab perdata secara langsung dari pelaku usaha (produsen barang) atas kerugian yang dialami konsumen akibat mengkonsumsi barang yang dihasilkan pelaku usaha;

3. Dalam hal terdapat hubungan perjanjian (kontrak) antara pelaku usaha (pemberi jasa) dan konsumen, tetapi prestasi pemberi jasa tersebut tidak terukur, sehingga merupakan perikatan usaha (inspanningsverbintenis), maka 
tanggung gugat pelaku usaha (pemberi jasa) didasarkan pada tanggung gugat profesional (professional liability). Tanggung gugat profesional ini menggunakan tanggung jawab perdata secara langsung dari pelaku usaha (pemberi jasa) atas kerugian yang dialami oleh konsumen akibat memanfaatkan jasa yang diberikan pelaku usaha (pemberi jasa).

Sebaliknya dalam hal terdapat hubungan perjanjian (kontrak) antara pelaku usaha (pemberi jasa) dan konsumen tetapi prestasi pemberi jasa tersebut terukur sehingga merupakan perikatan hasil (resultaatsverbintenis), maka tanggung jawab perdata pelaku usaha didasarkan tanggung gugat profesional (professional liability) dengan menggunakan tanggung jawab perdata atas dasar perjanjian (kontrak) (contractual liability) dari pelaku usaha (pemberi jasa) atas kerugian yang diberikan konsumen akibat memanfaatkan jasa yang diberikan pelaku usaha.

Secara umum prinsip-prinsip tanggung gugat dapat dibedakan menjadi :
1. Prinsip tanggung gugat berdasarkan atas unsur kesalahan (liability based on fault); 2. Prinsip praduga selalu bertanggunggugat (presumption of liability); 3. Prinsip praduga selalu tidak bertanggung gugat (presumption of non liability); 4. Prinsip tanggung gugat mutlak (strict liability); 5 . Prinsip pembatasan tanggung gugat (limitation of liability). ${ }^{7}$

Berikut ini secara singkat dijelaskan prinsip-prinsip tanggung gugat tersebut :

1. Prinsip tanggung gugat berdasarkan atas unsur kesalahan.

Prinsip tanggung gugat berdasarkan atas unsur kesalahan (fault liability atau liability based on fault) adalah prinsip yang cukup umum berlaku dalam hukum pidana dan hukum perdata. Roscoe Pound menyatakan bahwa "The French civil code made the idea of Aquilian culpa into a general theory of delictal liability, saying, "Every act of man which causes damage to another obliges him through whose fault it happened to make reparation". 8 Oleh

7 Sidharta, Hukum Perlindungan Konsumen Indonesia, Grasindo, Jakarta, 2000, h. 59.

\footnotetext{
${ }^{8}$ Roscoe Pound, op.cit., h. 81
} 
karena itu, BW menggunakan prinsip yang dianut oleh Code Civil Perancis, karena pada umumnya BW Belanda yang merupakan konkordansi di Indonesia mengikuti Code Civil Perancis. ${ }^{9}$ Prinsip ini diatur dalam BW pada pasal-pasal 1365, 1366 dan 1367.

Mengenai pembagian beban pembuktiannya, prinsip ini mengikuti ketentuan pasal 103 HIR (= Herziene Indonesische Reglement) dan pasal 283 $\mathrm{R} \mathrm{Bg}$ (Recht Reglement Buitengeweten) dan pasal 1865 BW, yang pada pokoknya mengatakan barang siapa yang mengaku mempunyai suatu hak harus membuktikan adanya hak atau peristiwa itu. Dalam prinsip ini juga berlaku umum untuk prinsip lainnya adalah definisi subyek pelaku kesalahan. Dalam doktrin hukum dikenal prinsip vicarious liability dan corporate liability.

Vicarious liability memberikan pengertian bahwa "majikan bertanggung jawab atas kerugian pihak lain yang ditimbulkan óleh

\footnotetext{
9 R.Soetojo Prawirohamidjojo dan Marthalena Pohan, Hukum Perikatan, tanpa penerbit, Surabaya, 1978, h.9.
}

orang/karyawan yang berada dibawah pengawasannya". 10 Roscoe Pound mengatakan, ......a liability without fault, developed out of noxal action ......, employers for injury by employees". 11

Sedangkan corporate liability memiliki pengertian yang sama dengan vicarious liability, yaitu "korporasi yang menaungi suatu kelompok pekerjaan mempunyai tanggung jawab terhadap tenaga-tenaga yang dipekerjakannya". 12

2. Prinsip praduga untuk selalu bertanggung gugat.

Prinsip ini didasarkan pada anggapan bahwa tergugat selalu bertanggung jawab (presumption of liability), sampai ia dapat membuktikan ia tidak bersalah. Jadi disini bebas pembuktian ada pada tergugat, sehingga dikatakan sebagai tanggung gugat dengan menggunakan sistem bebas pembuktian terbalik (omkering van bewijslast).

3. Prinsip praduga untuk tidak selalu bertanggung gugat.

\footnotetext{
${ }^{10}$ Sidharta, op.cit., h. 60 .

${ }^{11}$ Roscoe Pound, op.cit., h. 82.

${ }^{12}$ Sidharta, loc. cit.
} 
Prinsip ini merupakan kebalikan dari prinsip praduga untuk selalu bertanggung gugat, hanya dikenal dalam lingkup transaksi konsumen yang sangat terbatas, dan pembatasannya secara common sense dapat dibenarkan. ${ }^{13}$

4. Prinsip tanggung gugat mutlak.

Prinsip tanggung gugat mutlak atau dalam common law system dikenal dengan "Strict liability" adalah " $a$ person can be held liable for damage or injury even of not at fault or negligent". ${ }^{14}$

Dengan digunakan prinsip tanggung gugat mutlak ini, maka setiap konsumen yang merasa dirugikan akibat mengkonsumsi produk dapat menuntut ganti kerugian tanpa harus mempersalahkan ada atau tidaknya unsur kesalahan pada diri pelaku usaha (produsen).

Penggunaan prinsip tanggung gugat mutlak pada perlindungan konsumen

${ }^{13}$ Ibid., h. 62.

${ }^{14}$ Rate A. Howell (et.al.), Business Law, The Dryden Press, Hinsdale, Illinois, 1979, h. Glossary -23. menurut E. Saefullah berdasarkan alasan-alasan antara lain:

1. diantara konsumen disatu pihak dari pelaku usaha (produsen) dilain pihak maka beban kerugian (resiko) seharusnya ditanggung oleh pihak yang memproduksi/mengeluarkan produk yang menyebabkan kerugian bagi konsumen yang mengkonsumsi karena produk itu cacat/berbahaya;

2. dengan menempatkan/mengedarkan produk dipasaran berarti produsen menjamin produk tersebut aman dan pantas untuk dikonsumsi;

3. sebenarnya tanpa menerapkan prinsip tanggung gugat mutlakpun produsen yang melakukan kesalahan tersebut dapat dituntut melalui proses penuntutan beruntun, yaitu konsumen kepada pedagang eceran, pengecer kepada grosir, grosir kepada distributor, distributor kepada agen, dan agen kepada produsen. Penerapan prinsip tanggung gugat mutlak 
dimaksudkan untuk menghilangkan proses yang panjang ini. ${ }^{15}$

5. Prinsip tanggung gugat dengan pembatasan

Prinsip tanggung gugat dengan pembatasan (limitation of liability) dilakukan dengan mencamtumkan klausula eksonerasi dalam perjanjian baku yang dibuat oleh pelaku usaha. Rijken mengatakan klausula baku eksonerasi adalah klausula yang dicantumkan didalam suatu perjanjian dengan mana satu pihak menghindarkan diri untuk memenuhi kewajibannya dengan membayar ganti kerugian seluruhnya atau terbatas yang terjadi karena wanprestasi atau perbuatan melanggar hukum. ${ }^{16}$

\section{b. Tanggung Gugat Pelaku Usaha}

\section{Periklanan}

Pengelabuan yang dilakukan oleh pelaku usaha (produsen) terhadap konsumen melalui iklan akan menimbulkan

${ }^{15}$ Husni Syawali dan Neni Sri Imaniȳati (ed.), Hukum Perlindungan Konsumen, Mandar Maju, Bandung, 2000, h. 54.

16 Mariam Darus Badrulzaman, Aneka Hukum Bisnis, Alumni, Bandung, 1994, h. 47. kerugian bagi konsumen. Pelaku usaha didalam memasarkan produknya agar diketahui dan diminati oleh konsumen dilakukan melalui promosi. Promosi ini pada dasarnya merupakan komunikasi antara pelaku usaha (produsen) dan konsumen dengan tujuan agar penjualan roduknya makin meningkat, sehingga pada akhirnya dapat meningkatkan keuntungan pelaku usaha. Kegiatan-kegiatan promosi salah satunya dilakukan oleh pelaku usaha melalui iklan. Iklan pada dasarnya memberikan gambaran yang sebenarnya mengenai kegunaan dan manfaat dari produk tersebut. Bahkan iklan itu merupakan janji, sehingga menjadi daya tarik konsumen untuk menggunakan produk yang ditawarkan. Apabila iklan berisi kebohongan, maka apa yang disajikan dalam iklan itu berupa janji yang kosong, sehingga pelaku usaha menghianati kepercayaan khalayak, terutama konsumen yang langsung dirugikan. Disinilah menimbulkan sengketa hukum yang merugikan konsumen.

Mengelabui konsumen melalui iklan dapat dalam bentuk : 1. Iklan yang 
salah, 2. Pernyataan yang menyesatkan, dan 3. Iklan yang berlebihan.

Iklan yang mengandung "pernyataan yang salah" terjadi apabila dalam iklan dia mengungkapkan hal-hal yang tidak benar, misalnya menyatakan adanya suatu zat tertentu pada produk tersebut padahal tidak ada atau sebaliknya tidak ada padahal ada.

Iklan "yang menyesatkan" terjadi manakala iklan itu menggunakan opini subyektif untuk mengungkap kualitas produk tersebut secara berlebihan, tanpa didukung oleh suatu fakta tertentu. Sedangkan iklan "yang berlebihan" terjadi apabila menggunakan tiruan dalam visualisasi iklan.

Praktek mengelabuhi konsumen melalui iklan dapat diajukan gugatan ganti kerugian berdasarkan perbuatan melanggar hukum keapada pelaku usaha (pasal 1365 BW). Praktek yang mengelabuhi konsumen inipun dapat mengarah pada praktek perbuatan curang (tidak jujur) dalam bisnis, yang akan merugikan pelaku usaha sejenis lainnya. Pada sistem hukum perdata kita, dimungkinkan gugatan untuk memiñta ganti kerugian atas dasar tidak adanya hubungan kontraktual diantara keduanya dengan menggunakan dasar perbuatan melanggar hukum. Oleh karena itu, konsumen dapat mengajukan gugatan ganti kerugian kepada produsen sebagai pihak yang tidak berhubungan langsung dengan konsumen, dengan dasar hukum perbuatan melanggar hukum (pasal 1365 BW). Tidak adanya hubungan langsung (faktanya konsumen tidak membeli langsung dari produsen) bukanlah merupakan suatu alasan tidak bertanggung gugat. Penjualan produk yang telah dipromosikan lewat iklan di media masa langsung kepada konsumen, tidak ada alasan bagi produsen, bahwa tidak adanya hubungan langsung maka ia tidak bertanggung gugat. Produsen tetap bertanggung gugat apabila konsumen menanggapi iklan tersebut. Penggunaan pasal 1365 BW pada sengketa konsumen mengalami kesulitan dalam hal beban pembuktian, karena konsumen yang bertindak sebagai penggugat harus membuktikan unsur kesalahan dan hubungan kausal. Hal ini tentu akan menyulitkan konsumen untuk membuktikan karena keterbatasan kemampuan, pengetahuan, pengalaman, bahkan waktu dan biaya. 
Persoalan praktek mengelabuhi konsumen melalui iklan juga diatur oleh Undang-Undang Nomor 8 Tahun 1999 Tentang Perlindungan Konsumen dalam pasal 8 ayat (1) huruf $\mathrm{f}$, pasal $\mathrm{g}$ ayat (1), pasal 10 , pasal 12 , pasal 13 , sedangkan khusus untuk pelaku usaha periklanan diatur dakam pasal 17. Pasal 17 ini mengatur bahwa pelaku usaha periklanan dilarang memproduksi iklan yang :

a. mengelabui konsumen mengenai kualitas, bahan, kegunaan dan harga produk, tarif jasa, serta ketepatan waktu penerimaan produk;

b. mengelabui jaminan/garansi terhadap produk;

c. memuat informasi yang keliru, salah atau tidak tepat mengenai produk;

d. tidak memuat informasi mengenai resiko pemakaian produk;

e. mengeksploitasi kejadian dari/seseorang tanpa seijin, yang berwenang atau persetujuan yang bersangkutan;

f. melanggar etika dan atau ketentuan peraturan perundang-undangān mengenai iklan.
Persoalannya sekarang adalah apabila terjadi praktek mengelabui konsumen melalui iklan ini merupakan tanggung jawab pelaku usaha pengiklan (pelaku usaha yang mengiklankan produknya) atau pelaku usaha periklanan ? Atau dengan perkataan lain : apakah gugatan itu ditujukan kepada pelaku usaha pengiklan atau pelaku usaha periklanan atau ditujukan kepada keduanya berdasarkan tanggung gugat renteng? Mengenai hal ini Undang-Undang Perlindungan Konsumen mengatur tanggung gugat pelaku usaha dalam pasal 19 ayat (1), yang berbunyi : "pelaku usaha bertanggung jawab (baca : bertanggung gugat) memberikan ganti rugi atas kerusakan, pencemaran dan/atau kerugian konsumen akibat mengkonsumsi barang dan/atau jasa yang dihasilkan atau diperdagangkan".

Kemudian pasal 20 mengatur tanggung gugat pelaku usaha periklanan, yang menyatakan bahwa : "Pelaku usaha periklanan bertanggung jawab (baca : bertanggung gugat) atas iklan yang diproduksi dan segala akibat yang ditimbulkan oleh iklan tersebut". 
Penolakan pelaku usaha untuk memberikan ganti kerugian atas tuntutan konsumen, maka pelaku usaha dapat digugat melalui Badan Penyelesaian Sengketa Konsumen atau mengajukan ke Badan Peradilan (pasal 23).

Kemudian di dalam pasal 19 ayat (4) disebutkan bahwa "pemberian gantirugi tidak menghapuskan kemungkinan adanya tuntutan pidana berdasarkan pembuktian lebih lanjut mengenai adanya unsur kesalahan". Sedangkan terhadap ada tidaknya unsur kesalahan dalam kasus pidana merupakan beban dan tanggung jawab pelaku usaha tanpa menutup kemungkinan bagi jaksa untuk melakukan pembuktian. Ketentuan ini merupakan penerapan sistem beban pembuktian terbalik (pasal 22 dan penjelasannya).

Dari ketentuan-ketentuan tersebut diatas, maka dapat diambil kesimpulan sebagai berikut :

1. Meskipun

Undang-Undang Perlindungan konsumen telah mengatur tanggung gugat pelaku usaha, namun dasar gugatan dengan menggunakan pasal 1365 BW masih relevan, sebab kemungkinan penolakan ganti kerugian oleh pelaku usaha/pelaku usaha periklanan bisa terjadi dan membuka peluang mengajukan gugatan baik dengan menggunakan penyelesaian sengketa diluar pengadilan melalui Badan Penyelesaian Sengketa Konsumen maupun dengan menggunakan penyelesaian sengketa melalui pengadilan umum (lihat pasal 45, 47 dan 49);

2. Undang-Undang Perlindungan Konsumen telah memperkenalkan konsep sistem beban pembuktian terbalik untuk membuktikan unsur kesalahan kalau dilakukan tuntutan pidana;

3. Undang-Undang Perlindungan Konsumen secara tegas membebankan tanggung gugat periklanan kepada pelaku usaha periklanan, serta tanggung gugat baru ditujukan pada pelaku usaha, kalau konsumen dirugikan setelah mengkonsumsikan produk tersebut, artinya selama tidak menimbulkan kerugian konsumen akibat mengkonsumsi produk tersebut, maka pelaku usaha tidak bisa digugat 
meskipun telah terjadi praktek tanggung jawab pelaku usaha mengelabuhi konsumen melalui iklan; periklanan/pelaku usaha pengiklan. Dengan

4. Dalam sengketa konsumen, Undang- adanya putusan pidana mengenai perkara Undang Perlindungan Konsumen praktek mengelabuhi konsumen melalui memungkinkan adanya penggabungan perkara, yaitu mengajukan gugatan ganti kerugian melalui gugatan perdata dan juga mengajukan tuntutan pidana.

Nampaknya mekanisme untuk mengajukan gugatan ganti kerugian kepada pelaku usaha periklanan dan kepada pelaku usaha pengiklan masih menghadapi kendala-kendala karena masih menggunakan ketentuan pasal 1365 BW, yang tidak menggunakan sistem beban pembuktian terbalik untuk membuktikan unsur kesalahan. Namun, langkah meminta ganti kerugian dengan menggunakan pasal 1365 BW bisa dilakukan dengan menggunakan mekanisme penggabungan perkara yaitu, dilakukan pemeriksaan perkara pidana bersamaan dengan gugatan ganti kerugian. Pemeriksaan perkara pidana tidak mengalami kesulitan untuk membuktikan unsur kesalahan, karena menggunakan sistem beban pembuktian terbalik, artinya pembuktian ada tidaknya unsur kesalahan merupakan beban dan iklan yang telah mempunyai kekuatan hukum yang tetap maka terbuktilah kesalahan pihak pelaku usaha periklanan/pelaku usaha pengiklan yang menjadi salah satu syarat untuk gugatan ganti kerugian berdasarkan pasal 1365 BW. Barangkali persoalan yang timbul kemudian adalah proses yang demikian dalam praktek sangat jauh dari prinsip beracara yang sederhana, singkat dan murah.

Di Amerika Serikat, dalam hal terjadi praktek mengelabuhi konsumen melalui iklan, maka yang bertanggung jawab penuh atas kebenaran iklan adalah perusahaan periklanan. Bila perusahaan periklanan itu tidak dapat membuktikan kebenaran iklan, maka perusahaan periklanan yang akan bertanggung jawab atas kerugian, kecuali bila didepan pengadilan dia dapat mengalihkan tuntutan itu ke produksi, maka produsen 
bertanggung jawab atas kerugian. ${ }^{17}$ Bagaimana kalau persoalan tanggung-gugat pada praktek mengelabuhi konsumen melalui iklan dengan menggunakan tanggung gugat secara tanggung renteng (pelaku usaha periklanan dan pelaku usaha pengiklan).

Persoalan ini dapat dibandingkan dengan iklan pangan sebagaimana yang telah diatur dalam Peraturan Pemerintah Nomor 69. Tahun 1999 Tentang Label dan Iklan Pangan (untuk selanjutnya ditulis PP Label dan Iklan Pangan) sebagaimana pelaksanaan Undang-Undang Nomor 7 Tahun 1996 Tentang Pangan (UndangUndang Pangan). Mengenai iklan pangan diatur dalam pasal 44 sampai pasal $58 \mathrm{PP}$ Label dan Iklan Pangan. Setiap iklan tentang pangan yang diperdagangkan wajib membuat keterangan mengenai pangan secara benar dan tidak menyesatkan baik dalam bentuk gambar dan atau suara, pernyataan dan bentuk lainnya dan tidak boleh bertentangan dengan norma-norma kesusilaan serta dengan cara

${ }^{17}$ Hady Evianto, "Hukum Perlindungan Konsumen Bukanlah Sekedar Keinginan, Melainkan Kebutuhan", Hukum dan Pembangunan, Th.XVI, No.8 Desember 1986, h. 594. mendiskreditkan produk pangan lainnya. Mengenai tanggung jawab yang berkaitan dengan periklanan dimuat dalam pasal 45 PP Label dan Iklan Pangan, yang berbunyi:

1. Setiap orang yang memproduksi dan atau memasukkan ke dalam wilayah Indonesia pangan untuk diperdagangkan, dilarang memuat pernyataan dan atau keterangan yang tidak benar dan atau yang dapat menyesatkan dalam iklan;

2. Penerbit, pencetak, pemegang izin siaran radio atau televisi, agen dan atau medium yang dipergunakan untuk menyebarkan iklan, turut bertanggung jawab terhadap isi iklan yang tidak benar, kecuali yang bersangkutan telah mengambil tindakan yang diperlukan untuk meneliti kebenaran isi iklan yang bersangkutan.

Dari bunyi pasal tersebut dapat disimpulkan bahwa :

1. Pelaku usaha yang mengiklankan produknya dengan pernyataan dan atau keterangan yang tidak benar dan atau yang menyesatkan konsumen tidak secara tegas harus bertanggung gugat, namun di dalam ayat (2) disebutkan pelaku usaha periklanan (meliputi perusahaan iklan, media periklanan dan biro iklan) dikatakan turut bertanggumg gugat. Hal ini mengingatkan adanya 
tanggung gugat renteng, sehingga pelaku usaha pengiklan dikatakan peserta tanggung gugat (yang utama) terhadap iklan produknya yang tidak benar dan atau yang menyesatkan;

2. Untuk tanggung gugat pelaku usaha yang berkaitan dengan periklanan pangan ini, tentu mengacu pada pasal 41 ayat (1) Undang-Undang Pangan yang menggunakan prinsip strict liability manakala iklan yang tidak benar dan atau yang menyesatkan itu merugikan konsumen setelah mengkonsumsi pangan tersebut;

3. Untuk tanggung gugat pelaku usaha periklanan, dan atau (meliputi perusahaan periklanan, media periklanan, dan biro iklan) berlaku prinsip tanggung gugat dengan beban pembuktian terbalik, artinya pelaku usaha periklanan agar tidak turut bertanggung gugat apabila pelaku usaha periklanan dapat membuktikan bahwa mereka telah mengambil tindakan yang diperlukan untuk meneliti kebenaran isi iklan yang merugikan konsumen tersebut (prinsip presumption of liability).
Secara ideal iklan dirancang untuk menyajikan informasi yang jujur dan bertanggung jawab. Oleh karena itu, kreativitas iklan harus dirancang untuk menembak ratio konsumen, sehingga iklan dapat digunakan sebagai sarana mempromosikan nilai (value) produk tersebut. Didalam mendisain iklan, pelaku usaha periklanan hendaknya memperhatikan asas-asas umum kode etik periklanan, yaitu :

1. Iklan harus jujur, bertanggung jawab dan tidak bertentangan dengan ketentuan hukum yang berlaku;

2. Iklan tidak boleh menyinggung perasaan dan atau merendahkan martabat ,agama, tata susila, adat, budaya, suku dan golongan;

3. Iklan harus dijiwai oleh asas persaingan yang sehat.

Dalam rangka pembuatan iklan pada umumnya dapat diasumsikan sebagai berikut :

1. Inisiatif rencana desain dapat datang dari pelaku usaha pengiklan, kemudian oleh pelaku usaha periklanan secara kreatif diterjemahkan inisiatif tersebut kedalam bahasa periklanan untuk 
dibuatkan suatu iklan. Jadi konsep/ide dasar rencana iklan dari pelaku usaha pengiklan itu di kreativitas oleh pelaku usaha pengiklan sesuai dengan bahasa periklanan;

2. Kemungkinan terjadi pelaku usaha periklanan umumnya biro iklan hanya membuat iklan sesuai dengan pesanan, karena desain iklan sudah disiapkan oleh pelaku usaha pengiklan.

Masalah yang muncul mengenai tanggung gugat periklanan dalam rangka perlindungan konsumen adalah dalam 2 hal yaitu :

1. Bagaimana kalau informasi produk yang dituangkan dalam iklan tidak sesuai dengan kenyataan yang ada ?

2. Bagaimana kalau kreativitas pelaku usaha periklanan ternyata bertentangan dengan asas-asas kode etik periklanan ?

Dalam hal yang pertama, maka yang bertanggung jawab adalah pelaku usaha pengiklan, karena sudah menyangkut produk yang dijanjikan kepada konsumen melalui iklan. Hal ini berkaitan dengan larangan pelaku usaha memproduksi/memperdagangkan produk yang tidak sesuai dengan janji yang dinyatakan dalam iklan atau promosi penjualan produk tersebut (pasal 8 ayat (1) huruf $f$ Undang-Undang Perlindungan Konsumen). Selain itu, ada larangan pelaku usaha usaha dalam menawarkan produk yang ditujukan untuk diperdagangkan mengiklankan pernyataan yang tidak benar atau menyesatkan (pasal 10 UndangUndang Perlindungan Konsumen). Dengan instrumen hukum perdata, konsumen bisa meminta pertanggung jawaban pelaku usaha pengiklan dengan dasar wanprestasi apabila diketahuinya ketidaksesuaian janji dalam iklan dengan kenyataannya dibuktikan adanya hubungan kontraktual. Di samping itu, pertanggung-jawaban pelaku usaha pengiklan dengan menggunakan dasar perbuatan melanggar hukum apabila tidak ada hubungan kontraktual antara pelaku usaha pengiklan dan konsumen.

Sedangkan untuk hal yang kedua, yang bertanggung gugat adalah pelaku usaha periklanan dan pelaku usaha pengiklan secara tanggung renteng. Dalam pasal 20 Undang-Undang Perlindungan Konsumen mengatur bahwa "pelaku usaha periklanan bertanggungjawab (baca: 
bertanggung gugat) atas iklan yang diproduksi dan segala akibat yang ditimbulkan oleh iklan tersebut". Pelaku usaha periklanan harus menyadari bahwa yang dituju tidak hanya kepuasaan pelaku usaha pengiklan tetapi juga kepuasan konsumen yang

akan mengkonsumsi/menggunakan produk yang diiklankan. Pelaku usaha pengiklan merasa puas akan kreativitas pelaku usaha periklanan yang bernilai seni, lucu dan menghibur. Peningkatan penjualan suatu produk tertentu tidak lepas dari peran pelaku usaha periklanan melalui kreativitasnya. Namun, pelaku usaha periklanan seharusnya berhati-hati dalam menerima order, artinya pelaku usaha periklanan harus yakin terlebih dahulu bahwa produk yang akan diiklankan telah lolos uji keamanannya dari instansi yang berwenang. Misalnya dalam pembuatan dan penyajian kreativitas obat-obatan, maka pelaku usaha periklanan harus memperoleh keyakinan terlebih dahulu bahwa obat yang akan diiklankan sudah lolos uji kelayakan dikonsumsi dari Badan Pengawasan Obat dan Makanan (BPOM). Prinsip hati-hati yang harus dimiliki oleh pelaku usaha periklanan ini merupakan wujud untuk membantu pelaksanaan hakhak konsumen, seperti hak atas keamanan produk yang dikonsumsi konsumen.

\section{PENUTUP}

Mengenai persoalan sejauhmana tanggung gugat pelaku usaha periklanan atas iklan yang di produksi dapat disimpulkan dengan adanya kategorikategori sebagai berikut :

1. Pada dasarnya pelaku usaha periklanan bertanggung gugat atas iklan yang diproduksi berdasarkan prinsip professional liability. Meskipun dalam praktek dimungkinkan order itu hanya berupa pembuatan iklan dengan desain sepenuhnya dari pelaku usaha pengiklan atau harus dipenuhi persyaratan uji kelayakan dari instansi yang berwenang, maka pelaku usaha periklanan dalam keadaan kurang hatihati tetap bertanggung jawab penuh, karena secara profesional harus dapat menolak karena ada hal-hal yang bertentangan dengan kode etik periklanan; 
2. Tanggung gugat bisa menjadi tanggung gugat secara tanggung renteng antara pelaku usaha periklanan dan pelaku usaha pengiklan, manakala konsumen dirugikan setelah mengkonsumsi produk tersebut dapat dibuktikan juga adanya unsur kesalahan pada diri pelaku usaha karena dianggap menyetujui desain yang dikreativitas pelaku usaha periklanan;

3. Tanggung gugat pelaku usaha periklanan bisa beralih menjadi tanggung gugat pengiklan dengan menggunakan prinsip tanggung gugat dengan beban pembuktian terbalik manakala pelaku usaha periklanan dapat membuktikan bahwa pelaku usaha periklanan telah mengambil tindakan yang diperlakukan untuk meneliti kebenaran isi iklan yang merugikan konsumen.

\section{DAFTAR PUSTAKA :}

Badrulzaman, Mariam Darus, Aneka Hukum Bisnis, Alumni, Bandung, 1994.

Hady Evianto, "Hukum Perlindungan Konsumen Bukanlah Sekedar Keinginan, Melainkan Kebutuhan", Hukum Dan Pembangunan, Tahun XVI, No.8 Desember 1986.

Howell, Rate A. (et.al), Business Law, The Dryden Press, Hinsdale, Illinois, 1979.

Hasni Syawali dan Neni Sri Imaniyati (ed.), Hukum Perlindungan Konsumen, Mandar Maju, Bandung, 2000.

Nieuwenhuis, J.H., Pokok-Pokok Hukum Perikatan, Terjemahan Djasadin Saragih, tanpa penerbit, Surabaya, 1985.

Pound, Roscoe, An Introduction To The Philosophy of Law, The Colonial Press Inc., Clinton, Massachusetts, 1975.

Prawirohamidjojo, R. Soetojo dan Marthalena Pohan, Hukum Perikatan, tanpa penerbit, Surabaya, 1978.

Sidharta, Hukum Perlindungan Konsumen, Grasindo, Jakarta, 2000. 